\title{
Vertebrate fossils from the San José de Gracia quarry, a new Late Cretaceous marine fossil site in Puebla, Mexico
}

\section{Fósiles de vertebrados de la cantera San José de Gracia, un nuevo sitio fósil marino del Cretácico Superior en Puebla, México}

Jesús Alvarado-Ortega ${ }^{1, *}$, Kleyton M. Cantalice ${ }^{1}$, Jesús Alberto Díaz-Cruz ${ }^{2}$, Carlos Castañeda-Posadas ${ }^{3}$, Valentina Zavaleta-Villareal ${ }^{2}$

\begin{abstract}
Instituto de Geología, Universidad Nacional Autónoma de México, Circuito de la Investigación $\mathrm{S} / \mathrm{N}$, Ciudad Universitaria, Alcaldía Coyoacán, CDMX, 04510, Mexico.

${ }^{2}$ Posgrado en Ciencias Biológicas, Universidad Nacional Autónoma de México, Circuito de la Investigación S/N, Ciudad Universitaria, Alcaldía Coyoacán, CDMX, 04510, Mexico.

${ }^{3}$ Laboratorio de Paleontología, Facultad de Ciencias Biológicas, Benemérita Universidad Autónoma de Puebla. Edificio Bio-1, Ciudad Universitaria, Jardines de San Manuel, Puebla, 72570, Mexico.

* Corresponding author: (J. Alvarado-Ortega alvarado@geologia.unam.mx
\end{abstract}

\begin{abstract}
To cite this article:
Alvarado-Ortega, J., Cantalice, K. M., DíazCruz, J. A. Castañeda-Posadas, G., ZavaletaVillareal, V., 2020, Vertebrate fossils from the San José de Gracia quarry, a new Late Cretaceous marine fossil site in Puebla, Mexico: Boletín de la Sociedad Geológica Mexicana, 72 (1), A160819. http://dx.doi.org/10.18268/ BSGM2020v72nla160819
\end{abstract}

Manuscript received: 08/01/2018 Corrected manuscript received: 28/05/2018 Manuscript accepted: 30/05/2018

Peer Review under the responsability of Universidad Nacional Autónoma de México.

\section{ABSTRACT}

The San José de Gracia Quarry, located within the Municipality of Molcaxac, southern Puebla, Mexico, is a new paleontological site discovered about a decade ago. This paper is the first formal scientific contribution of this site. The quarry occupies an area no larger than the two hectares that is exploited for commercial purposes, where slabs are extracted from a marine sequence of cream-brown strata of poorly carbonated clays, with centimetric thickness. Although the upper and lower limits of this sequence are not known; the characteristic lithology and fossil content do not correspond with those of the regional geological units previously reported. Although the fossil association recovered from the San José de Gracia Quarry is composed mostly of fish remains; it also contains ammonites, belemnites, inoceramids, indeterminate ostreids, reptiles and few plant remains. In this work, the first fossil fish remains from this locality are described, including representatives of Enchodus and clupeid both previously known from Mexico; as well as the first record of Dercetis and Xenyllion from this country. In addition, a yaguarasaurine mosasaur is also reported. Based on its fossil content and its lithology, the fossil-bearing strata of the San José de Gracia quarry can be possibly referred to the Mexcala Formation (Morelos-Guerrero Basin) of Turonian age.

Keywords: San José de Gracia quarry, Turonian, Puebla, Mexcala Formation, vertebrates.

\section{RESUMEN}

La Cantera San Fosé de Gracia, ubicada dentro del Municipio de Molcaxac, al sur del Estado de Puebla, México, es un sitio paleontológico descubierto hace cerca de una década. Este trabajo representa la primera contribución científica formal. Esta cantera ocupa una superficie no mayor a las dos hectáreas explotadas con fines comerciales, donde se extraen lajas de una secuencia de origen marino, compuesta de margas arcillosas pobremente carbonatados depositadas en estratos paralelos, de color marrón-crema, cuyo grosor alcanza varios centímetros. A pesar de que los límites, superior e inferior, de esta unidad rocosa no son conocidos; sus características litológicas y contenido fósil no corresponden con aquellos de las unidades geológicas previamente reportadas para esta región. Aunque la asociación fósil recuperada de la Cantera San Fosé de Gracia se compone en su mayor parte de restos de peces; ésta también contiene amonites, belemnites, inocerámidos, ostreidos indeterminados, reptiles y muy escasos restos de plantas. En este trabajo se describen los primeros restos de peces fósiles de esta localidad, entre los que se destacan Enchodus, Laminospondylus y un clupeido, grupos ya previamente conocidos en México; así como el primer registro mexicano de Dercetis y Xenyllion. Aquí, también se reporta el hallazgo deun mosasaurio yaguarasaurino en México. Con base en su contenido fósil y su litología, se sugiere que los estratos fosilifferos de la Cantera San Fosé de Gracia son referibles posiblemente a la Formación Mexcala (Cuenca Morelos-Guerrero) y son de edad Turoniana.

Palabras clave: Cantera San José de Gracia, edad Turoniana, Formación Mexcala, Puebla, vertebrados. 


\section{Introduction}

In 2006, people of the San José de Gracia town, Municipality of Molcaxac, State of Puebla, central Mexico, began to exploit a deposit of sedimentary rocks within the limits of their communal property (Figure 1). In this site, herein formally named as "San José de Gracia quarry", cream-brown marly flagstones with reddish veins are extracted. Given its good appearance and resistance, these rocks are used to cover floors and walls. The artisanal procedures used during their extraction have allowed us to discover a peculiar fossiliferous association that we partially report in this contribution (see also Alvarado-Ortega et al., 2009, Pulido-González, 2011; Romero-García, 2013; Zavaleta-Villareal, 2015).

Fossils from the San José de Gracia quarry are scarce and poorly preserved if they are compared with those from the Tlayúa quarry, a Mexican emblematic Lagerstätte paleontological site located about $10 \mathrm{~km}$ south from Molcaxac town (Applegate et al., 2006). For this reason, the workers and traders of flagstones extracted in this new quarry have scorned the scientific and aesthetic

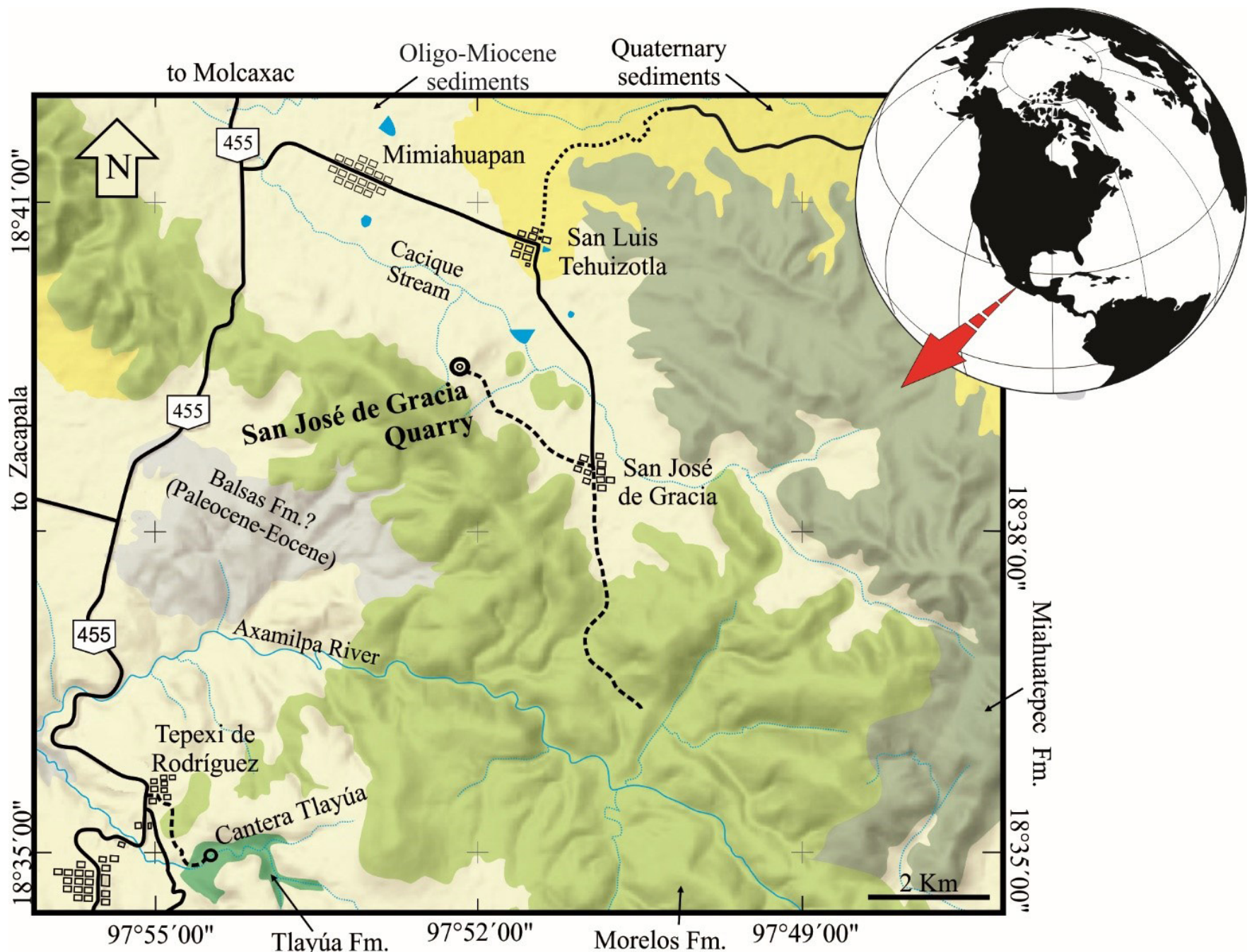

Figure 1 Map of San José de Gracia quarry showing the geological formations present in this region of Puebla, Mexico (based on map of Servicio Geológico Mexicano, 2006). 
value of their fossils; this has caused the loss or destruction of a great quantity of San José de Gracia specimens during the extraction and sale of these rocks.

In 2007, Messrs. Félix and Sebastián Arangu thy, traders of flagstones from different sources, inhabitants of Tepexi Rodríguez town (neighboring town of Molcaxac), and collaborators of the Tlayúa Paleontological Project, supported by the Instituto de Geología, Universidad Nacional Autónoma de México (UNAM), gave some fossils from the San José de Gracia to the first author of this work. Thus, in 2008, researchers of the UNAM and the Benemérita Universidad Autónoma de Puebla (BUAP), as well as workers of the San José de Gracia have worked together in order to recover fossils from this new locality, with the final goal of preserving and studying them formally. Currently, about 200 macrofossils from this quarry have been deposited in the scientific collections of UNAM and BUAP, including invertebrates (ammonites, belemnites, gastropods, bivalves, and crabs), vertebrates (fishes and reptiles), and scarce plant remains.
The San José de Gracia quarry is located 2.5 $\mathrm{km}$ west from the center of homonymous town, within the Municipality of Molcaxac, Puebla, central Mexico. This site is in the southeastern side of the Cacique Stream. Currently, the center of the quarry is at the altitude of 1930 m.a.s.l. and between the coordinates $18^{\circ} 39^{\prime} 27.25^{\prime \prime} \mathrm{N}$ and 97 ○ 52' 13.94" W. The exploited surface in San José de Gracia quarry extends about $150 \mathrm{~m}$ from East to West and $40 \mathrm{~m}$ from North to South (Figure 1).

Up to now, a sequence of about $4 \mathrm{~m}$ thick of decimetric marly strata has been exploited in the San José de Gracia quarry (Figure 2); which includes marl layers of clays poorly carbonated, showing normal gradation, and deposited in finely laminated parallel planes (Figure 2). Although the soil covers the geological features around the San José de Gracia Quarry making it impossible to recognize the presence of possible faults and contacts with other lithological units; the strata exposed in this quarry have a strike and dip that suggest the presence of an anticline. At the eastern end of the quarry the strike is variable between $\mathrm{N} 50-88^{\circ} \mathrm{W}$, while in the west this geomorphological feature is
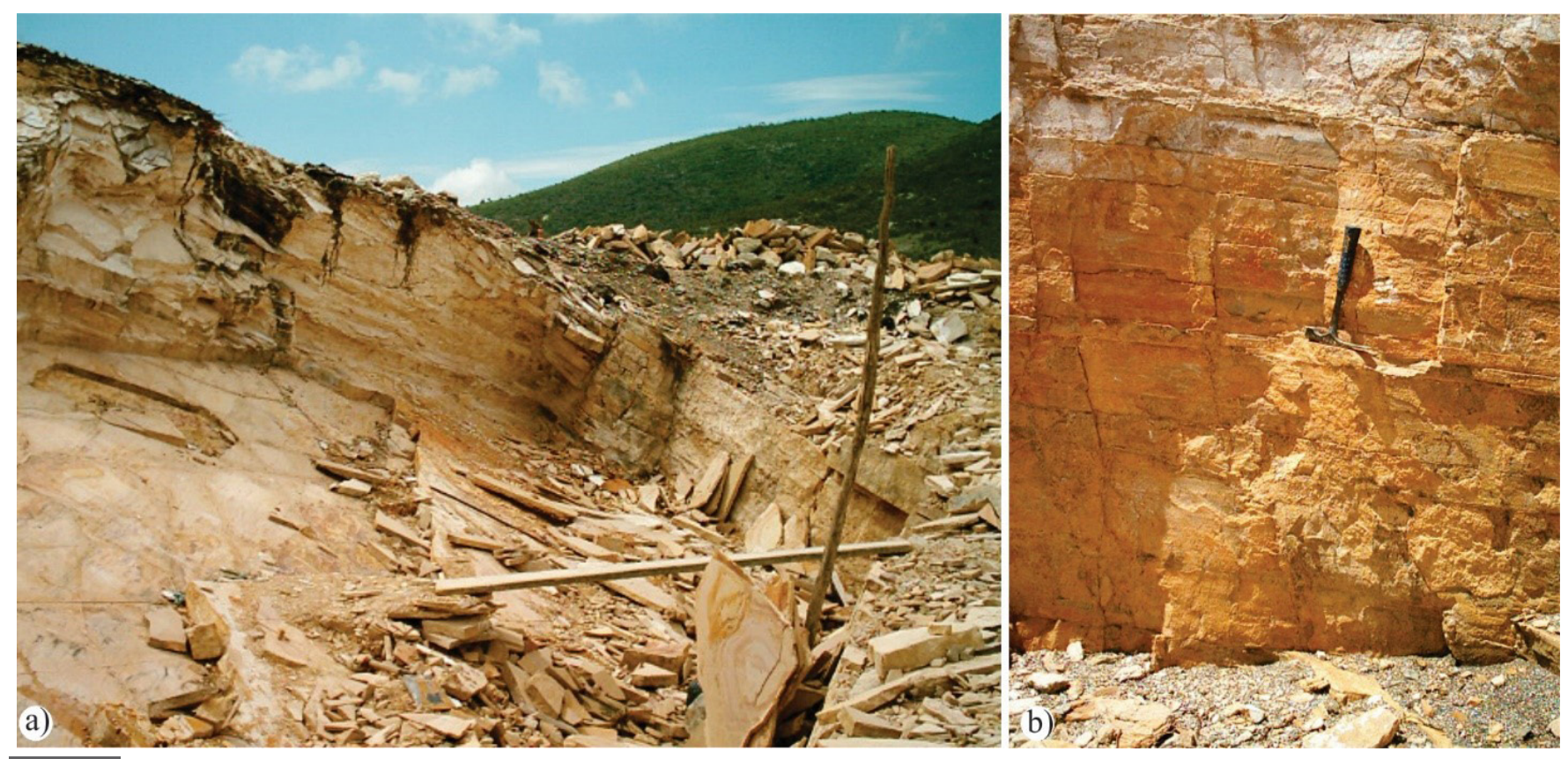

Figure 2 The San José de Gracia quarry; a) general view of one of the exploited sections in this quarry; b) Details of the San José de Gracia quarry showing the centimetric marl strata. 
close to $\mathrm{N} 90^{\circ} \mathrm{W}$. At the same time, the dip in these layers is variable between $23-35^{\circ} \mathrm{S}$ and $23-40^{\circ} \mathrm{S}$ respectively (Figure 2). As it is noted in the results of this work, the hitherto known fossil assemblage of San José de Gracia quarry includes Late Cretaceous marine vertebrates and invertebrates.

Since our first glance at the fossils from the San José de Gracia quarry, we recognized that they represent a peculiar assemblage preserved into a distinctive lithology, never observed in this region of Puebla. Therefore, we are convinced that this fossil assemblage deserves to be recognized in greater detail. Thus, the aim of this contribution is to report the San José de Gracia fossils and describe the geological details of this paleontological site.

\section{Materials and methods}

Preparation methods: Fossils were mechanically prepared with needles and odontological scavengers under stereoscopic microscope. When necessary, the fossils were glued with cyanoacrylate; they were hardened with weak solution of plexigym diluted in methacrylate acetate applied with a fine brush.

Institutional abbreviations: Fossils from the San José de Gracia are deposited and catalogued under the acronym IGM that corresponds to the Colección Nacional de Paleontología, housed into the Instituto de Geología, UNAM, as well as BUAPALZ that is the acronym of the Colección de Paleontología of BUAP. The San José de Gracia quarry is recorded in the catalog of paleontological sites of IGM as IGM-loc 3876.

Anatomical nomenclature and abbreviations: The taxonomical identification of fossil taxa described here, as well as the anatomical nomenclature and abbreviations used here (Figure 3 to 8 ), are based on the publications respectively cited.

\section{Results}

\subsection{FOSSIL VERTEBRATE ASSEMBLAGE OF SAN JOSÉ} DE GRAGIA

\subsubsection{SYSTEMATIC PALEONTOLOGY}

Order Clupeiformes sensu Grande, 1985

Suborder Clupeoidei sensu Grande, 1985

Family Clupeidae Cuvier, 1817

Genus and species indeterminate

Referred material: IGM $11190 \mathrm{~A}$ and B, part and counterpart, fairly complete specimen without the jaws and fins (Figure 3).

Description: This almost complete specimen preserved in part and counterpart shows the trunk strongly curved, reaches $40 \mathrm{~mm}$ of standard length (SL), with none of its fins is preserved. In life this should be a chubby fish, with a triangular head and a shallow caudal peduncle, in which the maximum height of the trunk was about $13 \mathrm{~mm}$.

Although the skull is poorly preserved, it is possible to observe that the skull roof bones are smooth. In addition, the parietals have the supratemporal commissure and are laterally displaced, separated by the supraoccipital bone. In the ethmoid region, both the mesethmid and vomer are well preserved, the first is located just above of the latter bone. The bones of both jaws are not preserved in this specimen; hence, the hyoid bones are partially exposed showing that the anterior ceratohyal is an elongated, rectangular, and no pierced bone.

There are thirty-four centra in the vertebral column, including 18 abdominals, 14 caudals, and two urals. The abdominal and caudal centra are somewhat distorted in IGM 11190; however, they seem to be rectangular, slightly higher than long. Probably, this fish has 16 preural ribs. Since the trunk is entirely scaled, it is not possible to see more 

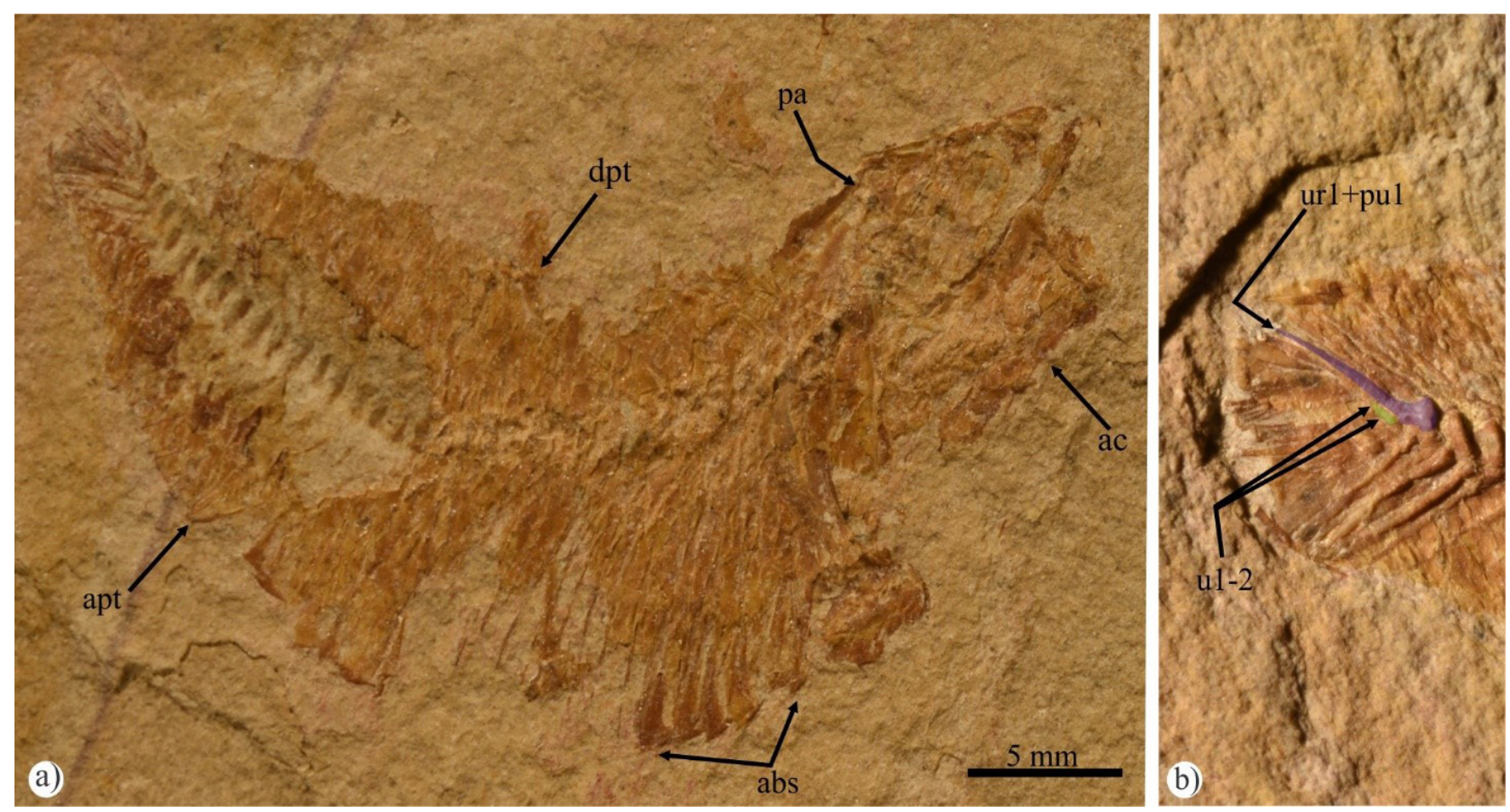

Figure 3 Specimen IGM 11190, representative of an indeterminated genus and species belonging to of the family Clupeidae from the San José de Gracia quarry; a) general view of the specimen; b) closeup of the caudal fin. Abbreviations: abs, abdominal scutes; ac, anterior ceratohyal (no pierced); apt, anal pterygiophore; dpt, anal pterygiophore; pa, parietal; ur 1+pu1, ural 1 and pleural centrum 1 fused; u 1-2, ural centra 1 and 2.

details of the vertebral column and associated bones.

The pectoral fin is not preserved; however, in the pectoral girdle the cleithrum is a $\mathrm{G}$ shaped bone that is slightly widened at its ventral end. Behind this bone, there are two postclithra, the dorsal one is ovoid and the ventral one is rod-like. The single visible dorsal pterygiophore shows that the dorsal fin rises near to the middle of the SL. There are 10 visible anal pterygiophores showing that the anal fin is located between 75 and $82.5 \%$ of the SL (30 and $35 \mathrm{~mm}$ ). The pelvic and caudal fins are not preserved.

The trunk entirely covered for ovoid cicloid scales, taller than long, ornamented with numerous concentric circulli. No dorsal scutes are preserved in this fish. A ventral row of at least 14 abdominal scutes extends between the isthmus and the first anal pterygiophores. The abdominal scutes are triangular; they have a thickened ventral edge that projects back and forth from small spines, as well as a laminar triangular wing slightly curved forward, directed upward, and covering lest than one third of the abdominal area below the vertebral column. These scutes barely overlap each other, leaving space to observe the extension of the ribs. In the caudal skeleton, the preural 1 and the first uroneural bone are fused and there is a caudal diastema present between the hypurals 2 and 3 .

Remarks: IGM 11190 is recognized as part of the Clupeoidei (Clupeomorpha, Clupeiformes) because it shows the diagnostic features of this clade, described by Grande, 1985). This has the abdominal scute series as all clupeomorphs; its parietals are entirely separated by the supraoccipital bone and its anterior ceratohyal is not medially pierced due the loss of the beryciform foramen, as occur in all clupeiforms (see Grande, 1985); additionally, as in all clupeoideis, this specimen shows the fusion of the first uroneural with the first preural centrum, the ural centra are relatively small in relation with the most caudal preural centrum, 
confirms that this fish belongs to the mentioned Suborder.

In addition, based on data from Grande (1985), it is possible to consider IGM 11190 as part of the superfamily Clupeoidea. The number of pleural ribs to pleural vertebrae ratio of IGM 11190 $(15 / 32)$ is 0.46 and matches with that known for members of this clade (0.47 to 0.71$)$.

The family Clupeidea is an ancient living group with a fossil record dating back to the Barremian-Aptian (Early Cretaceous) in marine deposits of the Morro de Chaves Formation, northeastern Brazil (Figuereido, 2009; Lavoué et al., 2013; Malabarba and Di Dario, 2017). Although, IGM 11190 deserves an accurate study; additional fossil materials are required to reach an accurate taxonomical determination of this clupeid fish.

Order Aulopiformes Rosen, 1973

Family Dercetidae Woodward, 1901

Genus Dercetis Agassiz, 1833

\section{Dercetis sp.}

Type species: According Taverne (2005a) the type species of this genus is Dercetis elongatus Agassiz, 1833 (p. 258). The first reference of this genus was published by Agassiz (1833, p. XLIII) but its description was published ten years later by Munster and Agassiz, 1843 (in Agassiz, 1843, p. 258), from the Turonian and Senonian marine deposits of England [Goody (1969) recognized Dercetis scutatus Agassiz, 1834, from the Turonian and Campanian deposits of Baumberg, in Westphalia, Northweastern, Germany, as the type species of Dercetis; however, this can be considered a nomen nudum because the single specimen of this species was never illustrated and now is lost].

Referred material: IGM 11191, an elongated almost complete fish without caudal fin exposing its left side (Figure 4).

Description: IGM 11191is an elongated and longirostrine fish of at least $140 \mathrm{~mm}$ length that exposes its left lateral surface, in which the caudal fin is not preserved (Figure 4). The head is $10 \mathrm{~mm}$ high and $38 \mathrm{~mm}$ length. The skull length is about $30 \mathrm{~mm}$; this is divided into the length of orbitalpostorbital and preorbital (= snout) regions, which lengths are 12 and $18 \mathrm{~mm}$ (or 40 and $60 \%$ of the skull length) respectively. The elongated trunk is slightly lower and uniformly high all along.

Although bad preserved, in the head both jaws are projected forward to the same level. The dentary shows two rows of slightly curved, conic teeth, of similar size. The premaxilla has a discernible wide and high ascending process. The right frontal bone is almost entirely lost; however, above the orbit the surface of this bone has some small tubercles.

This fossil preserves seventy vertebrae showing the shape of thread reels, in which the intervertebral articulation surfaces are wide and massive while their middle part is strongly constricted. Although, the vertebrae are about 1.5 time longer than high in the abdominal region; they tend to be less long. The last two vertebrae preserved in this specimen, probably the first preural centra, are slightly higher than long. A single transverse process laterally rises from the anterior half of each abdominal centra. At least 40 vertebrae are abdominal and attach with thin preural ribs. The neural and hemal spines are short and curved backward. Numerous epineurals and epipleurals are present all along the trunk.

The pectoral fin is behind the middle of the pectoral girdle, between the vertebral column and the abdominal border of the trunk and consists of 11 rays. The pre-pelvic distance is $55 \mathrm{~mm}$; this fin is located $25 \mathrm{~mm}$ behind the pectoral girdle, is opposed to the middle part of the dorsal fin consisting of at least 5 rays. The dorsal fin is $52 \mathrm{~mm}$ length and is located between the $54 \mathrm{~mm}$ (= predorsal length) and $106 \mathrm{~mm}$ of the fish length consisting of about 40 rays. The anal fin is extremely short; its length is juts about $8 \mathrm{~mm}$ and it is located between the $110 \mathrm{~mm}$ (= preanal length) and 118 $\mathrm{mm}$ of the fish length consisting of eight rays.

Although these are poorly preserved, it is possible to see that IGM 11191 has three rows of smooth and triradiate scutes along the body; one 

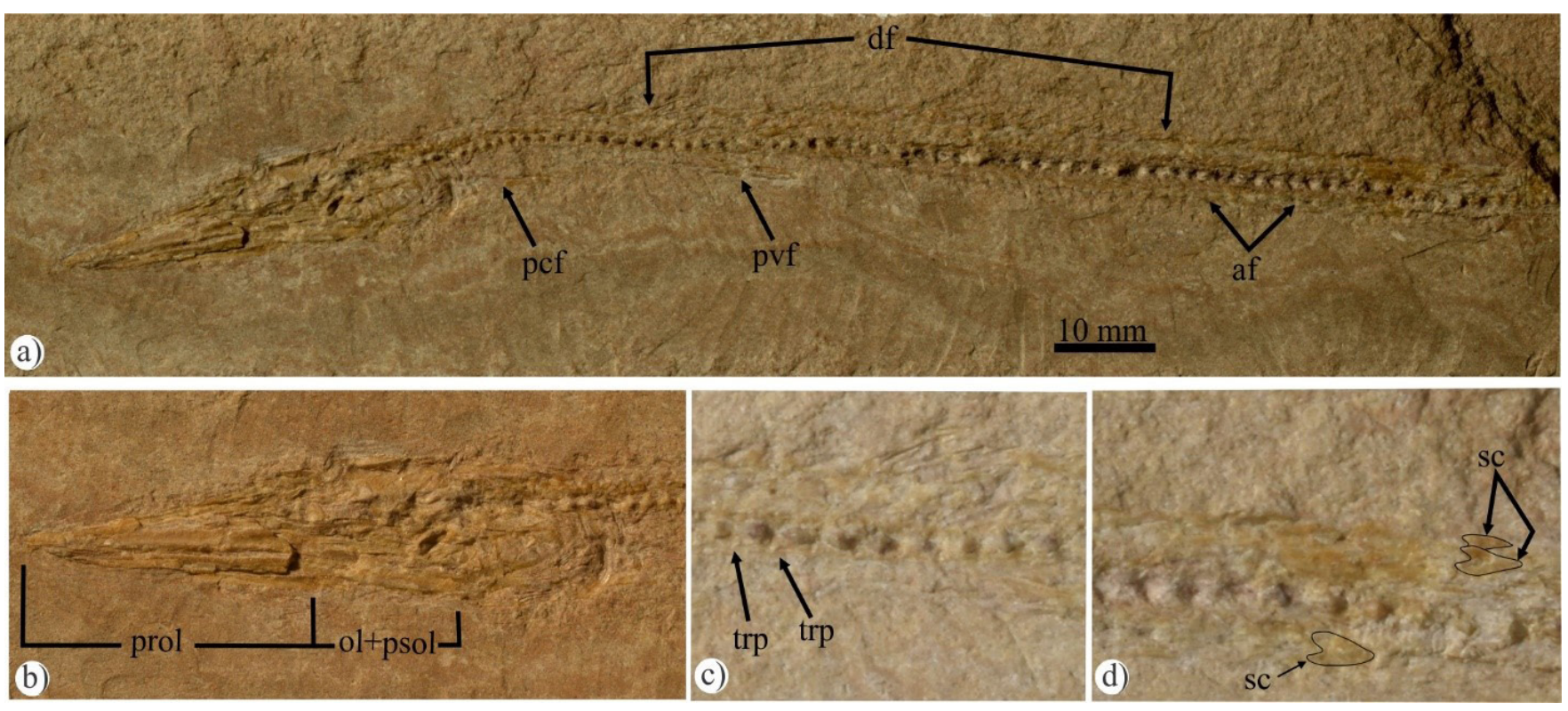

Figure 4 Specimen IGM 11191 , Dercetis sp. from the San José de Gracia quarry; a) general view of the specimen; b) Details of the head; c) close up of the abdominal region; d) close up of the posterior part of the trunk; Abbreviations: af, anal fin; df, dorsal fin; ol+psol, orbital length + postorbital length; pcf, pectoral fin; prol, preorbital length; pvf, pelvic fin; sc, scutes; trp, tranverse process.

along the dorsal body edge; another along the ventral body edge; and the last covers the flank of the trunk just above the vertebral column.

Remarks: Recently Vernygora et al. (2017) reviewed the phylogenetic relationship of 14 genera included in the clade Dercetidae; they point out that this family is supported on a single non-ambiguous synapomorphy: the presence of reduced neural spines. Other homoplasic features are the presence of shallow head, long snout, and arrow shaped flank scutes. IGM 11191 shows all these characters supporting its inclusion within this family.

Vernygora et al. (2017, suppl. 1) also revealed two monophyletic groups within Dercetidae. One of these groups includes Dercetis as sister group of Cyranichthys Taverne, 1987, and Ophiodercetis Taverne, 2005b; these three genera share the presence of ascending process in the premaxilla, a single pair of transverse processes on abdominal vertebrae, a long dorsal fin (with more than 20 rays) and more than one tooth row in the mandible. IGM 11191 is included within this Dercetis-Ophiodercetis group because it shows the first three of these characteristics.
Taverne (2006, fig. 13, p. 41-42) pointed out that Dercetis differs from other dercetid genera in at least four characteristics. Although in all dercetids the preorbital region or snout is elongated; in Dercetis the snout is relatively short and does not exceed $60 \%$ of the skull length. Contrary, in other dercetids the snout is considerably longer (at least two times than the orbito-postorbital part of the neurocranium), including the recently published Candelarhynchus Vernygora, Murray, Luque, Parra Ruge, and Páramo Fonseca, 2017. In Dercetis, the ascending process of the premaxilla is well developed whereas in other dercetids this disappear or is reduced to a tiny nodule. Here again, IGM 11191 show both features and its identification as a representative of Dercetis is undeniable.

Although once the genus Dercetis included a large number of species (see Goody, 1969; Silva and Gallo, 2011); today, two nominal species are included within the genus, the type species D. elongatus from Turonian-Senonian deposits of England and D. triqueter Pictet, 1850, from Santonian sediments of Sahel Alma, Lebanon. The temporal distribution of this genus could reach the limit of the Cretaceous if the finding of 
Dercetis in Maastrichtian sediments of Muwaqqar Chalk Marl Formation, near Harrana, Lebanon, reported by Kadummi (2006) is confirmed.

Both nominal species of Dercetis differ in the proportions of the skull, of the preorbital region of the cranium, the lengths of the preorbitalpostorbital regions of the skull are $60 \%$ and $40 \%$ in D. triqueter while in D. elongatus they are 50\% (Woodward, 1901, p. 184-185; Goody, 1969, p. 62). In the present context, IGM 11191 resembles $D$. triqueter; however, it is desirable to have more specimens from San José de Gracia before reaching a conclusion. At this time, IGM 11191 is referred to as an indeterminate species of the genus Dercetis; however, it is noticeable that this specimen represents the first finding of this genus in America.

Family Enchodontidae sensu Fielitz, 2004

Genus Enchodus Agassiz, 1833 (p. XLIV)

\section{Enchodus sp.}

Type species: Enchodus lewesiensis (Mantell, 1822), Turonian and Senonian rocks of the Middle Chalk in Lewes, Sussex, southeastern England (Goody, 1969).

Referred material: IGM 11192, a complete palatine bone bearing an incomplete tooth (Figure $5)$.

Description: IGM 11192 includes an almost complete palatine bone that is exposed on its labial surface. This stout bone and its terminal tooth form a squad-like structure. The palatine is 42.97 long and $7.43 \mathrm{~mm}$ high; its ventral edge is almost straight and the dorsal is slightly curved (Figure 5). The medial surface of this massive bone is rounded and practically smooth, being wider along and near its ventral edge. A shallow groove for the palato-premaxillary ligament is projected backward from the middle of the dorsal edge of this palatine; unfortunately, neither the end of this grove nor the groove for the palate-maxillary ligament are preserved. The palatine has a remarkable wide rounded cavity with rough surface

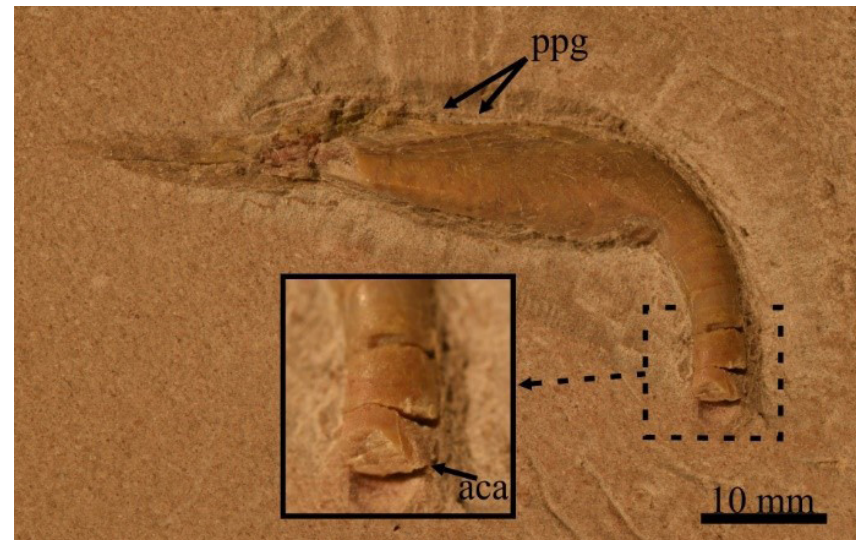

Figure 5 Specimen IGM 11192 , Enchodus sp. from the San José de Gracia quarry, showing a close up of the palatine tooth in cross section. Abbreviations: aca, anterior carina; ppg, groove for the palato-premaxillary ligament.

opening on the lateroventral surface of the bone just behind the palatine tooth.

Although, the tip of the single stout palatine tooth is not preserved; this ankylosed structure should be straight and smooth. The basal and preserved part of this tooth is $11 \mathrm{~mm}$ measured from the ventral surface of the palatine; however, its total length could reach $20 \mathrm{~mm}$ or about $50 \%$ of the palatine length. This tooth is slightly tilted forward forming an obtuse angle, of about $100^{\circ}$, with the ventral edge of the palatine. The position of this tooth also is clearly terminal, the palatine does not project in front of this tooth. The broken surface of the palatine tooth is ovoid, compressed laterally, and has an anterior cutting edge or carina (Figure 5).

Remarks: The genus Enchodus, commonly named as saber-tooth fish, consists of about 70 nominal species, being the most diverse fossil member of the family Enchodontidae (Order Aulopiformes). The species of Enchodus were active Upper Albian-Eocene marine predators that inhabited practically all the seas of the planet (Fielitz and González-Rodríguez, 2010). In Mexico, fossil of Enchodus have been collected in numerous Albian-Maastrichtian deposits throughout Coahuila, Tamaulipas, Nuevo Leon, San Luis Potosi, Hidalgo, Guerrero, and Chiapas (Maldonado-Koerdell, 1956; Blanco-Piñón 1998; 
González-Barba and Espinosa-Chávez, 2005; Alvarado-Ortega et al., 2006a, 2006b; Giersch et al., 2008; Díaz-Cruz et al., 2016; among others); however, only five species have been identified in Mexico at the species level.

These comprise complete specimens of the species E. zimapanensis Fielitz and GonzálezRodríguez, 2010, from Albian-Cenomanian deposits of the Muhi quarry, Hidalgo, central Mexico; isolated palatine teeth referred to $E$. petrosus Cope, 1874, E. gladiolus (Cope, 1875), and E. ferox Leidy, 1855, from Maastrichthian deposits of the Ocozocuautla Formation, Chiapas, southern Mexico, (Carbot-Chanona and ThanMarchese, 2013); as well as possible representatives of E. venator Arambourg, 1954 from the Turonian deposits of Vallecillo quarry, Nuevo León, northern México, which were reported by Giersch (2014) as E. cf. venator. Among these, E. zimapanensis is a remarkable because it represents the oldest species known of the genus (Albian-Cenomanian) and the only species restricted to Mexico.

Despite its taxonomic richness, in the most recent systematic studies on Enchodus, only 18 species have been considered (Goody, 1976, Chalifa, 1996, Bogan and Agnolin, 2010, among others) and just 14 of them were included into the last phylogenetic approaches (Fielitz, 2004; Fielitz and González-Rodríguez, 2010; Cavin et al., 2012; Díaz-Cruz et al., 2016; Holloway et al., 2017; among others). Considering the results of Díaz-Cruz et al. (2016); the presence of a single palatine tooth is a homoplasic condition shared only for Rharbichthys ferox Arambourgh, 1954 and all members of the family Enchodontidae menus Unicachichthys multidentatus Díaz-Cruz, AlvaradoOrtega and Carbot-Chanona, 2016. Unicachichthys is a peculiar enchodontid fish, in which the palatine is multidentated.

Among enchodontids with a single palatine tooth, the cross section of this tooth is symmetrical, ovoid, and shows a single anterior carina (unicarinated) only in five species, including $E$. shumardi Leidy, 1856; E. dirus, Leidy, 1857; as well as E. gladiolus, E. zimapanensis, and the unnamed
Enchodus species from Gavdos (Parris et al., 2007; Fielitz and González-Rodríguez, 2010; Cavin et al., 2012; Holloway et al., 2017; among others). In contrasts, in other enchodontids in which the palatine tooth is known, the cross section of this tooth is rounded without carinae or laterally compressed and bi-carinated. In Rharbichthys ferox this tooth is also ovoid in cross section and unicarinated; however, this species clearly differs from IGM 11192 and the nominal Enchodus spp. because its single palatine tooth is strongly tilted forward and so extremely developed that it is noticeably longer than the palate bone (Fielitz, 2004, fig. 4E). Moreover, among the group of five species of Enchodus noted above, in E. zimapanensis and the unnamed Enchodus species from Gavdos the palatine tooth shows longitudinal striations (Fielitz and González-Rodríguez, 2010; Cavin et al., 2012) whereas in E. shumardi, E. gladiolus, and E. dirus this tooth is entirely smooth (Parris et al., 2017).

Although the palatine tooth of IGM 11192 shares the characteristics discussed above with Enchodus shumardi, E. gladiolus, and E. dirus, including a smooth its palatine that in cross section is symmetrical, ovoid, and is uni-carinated (Figure $5)$; it is not possible to advance further in the attempt to determine the taxonomic identity of this fossil from San José de Gracia quarry. Another feature shared by IGM 11192 and these same species is the anterior terminal position of the palatine tooth. Although this feature deserves to be analyzed in greater detail and beyond the scope of this work; it is noteworthy that in other species of Enchodus where the palatine is well known, as well as in Rharbichthys ferox, the palatine tooth is not terminal because this bone has a projection in front of the tooth base (Goody, 1969, fig. 36; Fielitz, 2004, fig. 4E; Chalifa, 1996; figs. 3, 5, 6; among others).

Nonetheless, the taxonomical approximation of IGM 11192 with the three nominal Enchodus species noted above is geographically congruent since all of them are present only in North Ame rica, within a range between Late Cenomanian 
and Early Maastrichthian (Parris et al., 2007). The distribution of Enchodus gladiolus includes Maastrichthian deposits of the southern part of México (Carbot-Chanona and Than-Marchese, 2013) and probably also reaches Maastrichthian deposits of South America (Bogan and Angolin, 2010). Although based on the present context, IGM 0001 is considered as an uncertain species of Enchodus; its morphological features suggest that it is related with or belongs to some one of these three North American Enchodus species.

\section{Order Sphenocephaliformes Rosen and Patterson, 1969}

Family Sphenocephalidae Patterson, 1964

Genus Xenyllion Wilson and Murray, 1996

\section{Xenyllion sp.}

Type species: Xenyllion zonensis Wilson and Murray, 1996, from the Early Cenomanian deposits of the Fish Scale Formation, in Alberta, Canada.

Referred material: IGM 11193, complete and articulated specimen (Figure 6).

Description: High diamond shaped fish, with the skeleton completely preserved but with the trunk somewhat curved upward. In this fish the standard length is about $18 \mathrm{~mm}$, the head length is about $7 \mathrm{~mm}$, and the body height is $8 \mathrm{~mm}$. The short dorsal fin consists of 4 thin spines plus six or seven rays; it is located just at the end of the first half of the SL (predorsal length = 8mm). The anal fin is short, is composed of at least four thin spines plus eight rays, and located in the last quarter of the SL (preanal length $=14 \mathrm{~mm}$ ). The pectoral fin consists of about 10 rays and is located just above the ventral border of the trunk. The pelvic fin consists of about seven rays plus an anterior rudimentary (short) spine; this fin is located in the middle of the distance between the pectoral and the anal fin base, opposed to the middle part of the dorsal fin (Figure 6).

Although bones of the head are strongly cracked, the skull is triangular, with a high supraoccipital crest, and mainly roofed by the frontal bones. The lower jaw is projected upward from the posterior edge of the orbit. The premaxilla is about triangular with ascending process as short as the articular process, which is separated by a shallow notch. The maxilla is a bar-like structure projected up to the anterior end of the premaxilla. No teeth are exposed.

The preopercle is almost entirely preserved as an impression; however, its shows a short horizontal limb, whose length is contained four times in the height of the vertical limb of this bone. Both preopercular limbs form an angle of about $90^{\circ}$. There is an impression of a lateral flange along the way of the preopercular sensory canal, which seems to be open along a groove. The posterior edge of this preopercular flange is sinuous. Also, there are impressions of two long spines in the posteroventral preopercular edge.

Vertebral column consists of 26 centra, including about 13 abdominals, 11 preurals, and two urals. About 12 thin and short preural ribs are present just covering the dorsal half of the abdominal ca vity. Neural and hemal arches are small and their respective spines are thin. Some epineurals and epipleurals are preserved; however, their position, number, and sizes are unclear. There is a single supraneural bone located above the neural spines of the anterior abdominal centra. In the caudal skeleton, the preural 2 bears a complete, long, and thin neural spine. The preural 1 has a triangular short neural arch and above of this, there are two epineurals. The trunk is covered with cicloid scales with crenate posterior edge and strong circuli on the anterior half.

Remarks: Sphenocephalidae is a family of extinct acantomorph marine fishes erected by Patterson (1964): the species Sphenocephalus fissicaudus Agassiz, 1839 (p. 4), from the Campanian deposits of Baumberg, Westphalia, Germany. Later, another German species from Sendenhorst, Westphalia, was described as Sphenocephalus brachypterygius Rosen and Patterson, 1969. Recently, Xenyllion zonensis Wilson and Murray, 1996, from the Early Cenomanian deposits of the Fish Scale Formation, in Alberta, Canada, was described 


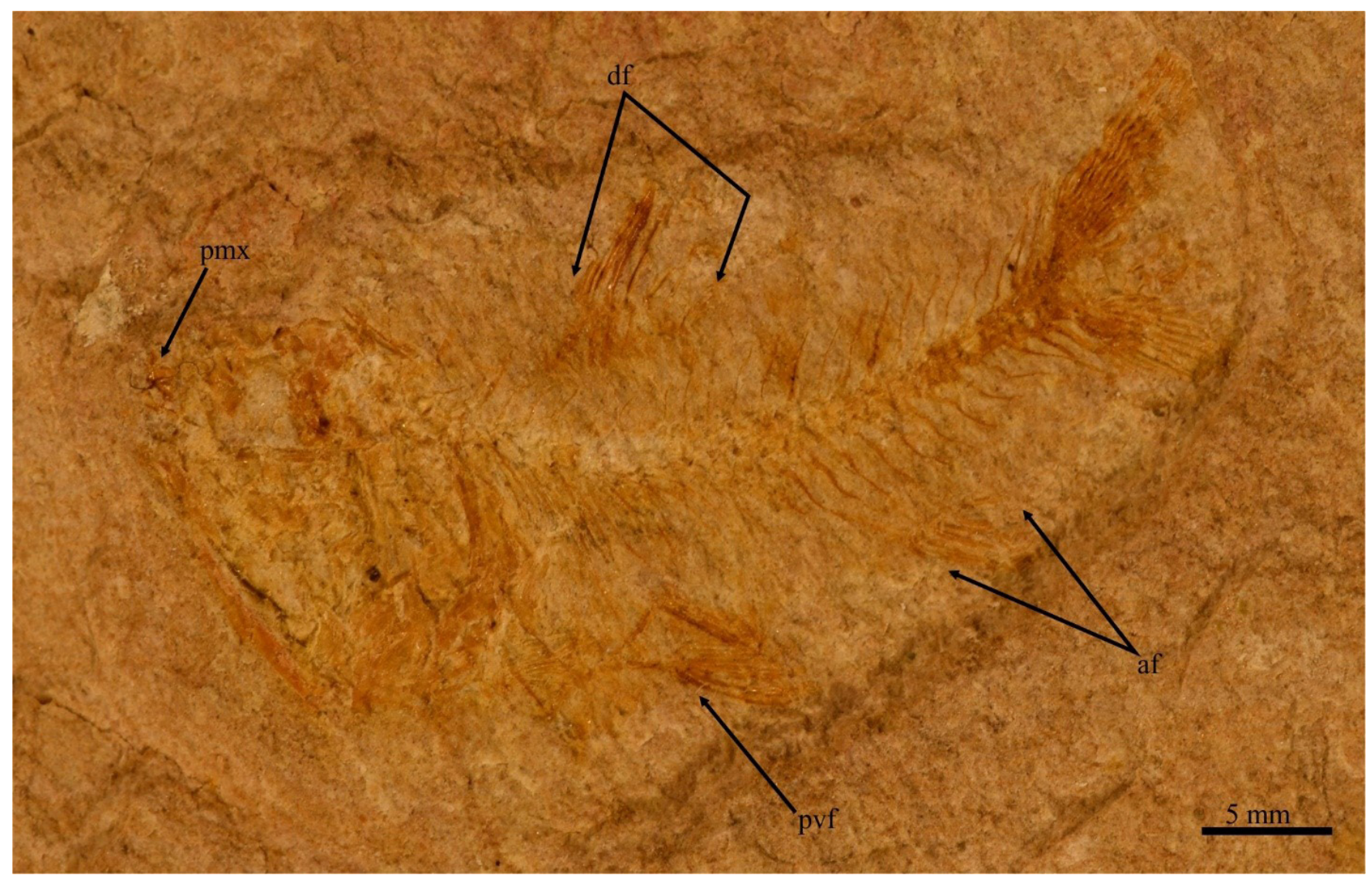

Figure 6 Specimen IGM 11193 , Xenyllion sp. from the San José de Gracia quarry. Abbreviations: af, anal fin; df, dorsal fin, pcf, pectoral fin; pmx, premaxilla; pvf, pelvic fin.

as a new sphenocephalid member. Finally, $X$. stewarti, Newbrey, Murray, Wilson, Brinkman and Neuman, 2013, from the Early Cenomanian deposits of Mowry Formation in Vernal, Utah, USA was described and added to Xenyllion. In the following paragraphs, it is demonstrated that IGM 0005 is a member of the family Sphenocephalidae and the genus Xenyllion.

The presence of dorsal and anal spines in this fish support its inclusion within Acantomorpha, a group well characterized for the presence of spines in the dorsal and anal fins (Nelson et al., 2016). The Paracanthopterygii is a problematic group of living fishes, with the oldest record dating back to the Cenomanian (Newbrey et al., 2013). This group was named by Greenwood et al. (1966) as a Superorder and since then its monophyly and composition have been discussed (Rosen and Patterson, 1969; Wiley and Johnson,
2010; Borden et al., 2013; among others). The presence of a complete neural spine on second preural, two epipleurals in the caudal support, and a single supraneural present are features of Paracanthopterygii (see Greenwood et al., 1966, p. 352, 353) and Murray and Wilson (1999) that are seen in the specimen IGM 11193.

One of two diagnostic characters of the order Sphenocephaliformes described by Rosen and Patterson (1969) are present in IGM 11193, its preopercle has large posteroventral spines. The other of these features, the opercle with posteroventral edge curved, is unknown in IGM 11193. Additionally, this Mexican specimen shows some characters included in the diagnosis of the single family of this order. According to Patterson (1964) and Newbrey et al. (2013), the diagnostic characters of Sphenocephalidae include the presence of a pelvic splint (= rudimentary anterior spine), 
seven pelvic fin rays, as well as anal and dorsal fin with four to five spines each.

Newbrey et al. (2013) provided a comparative exercise between the four sphenocephalid species. Based on their results, IGM 11193 is identified here as a new representative of the genus Xenyllion because they share two characteristics: the trunk is covered with crenate cycloid scales, and the preopercle shows similar proportions (both limbs form an angle of $90^{\circ}$ and the horizontal limb is short and contained four times in the height of the preopercular vertical limb). In contrast in both Sphenocephalus species, the preopercles have a relatively long horizontal limb (its length is the half of the height of the vertical preoperclar limb) and both limbs form a posteroventral obtuse angle of about $120^{\circ}$; S. fissicaudus has oval spinoid cycloid scales whereas $S$. brachypterygius are rather rounded, apparently do not show spines, and the circuli form a triangular wave-form pattern.

The poor preservation of the skull in IGM 11193 prevents carrying out a deeper comparative analysis to determine its taxonomic identity with better precision. Despite this, the finding of IGM 11193 represents the first occurrence of a sphenocephalid fish in Mexico and the expansion of the geographical distribution of the genus Xenyllion in America.

Orden Squamata Oppel, 1811

Superfamily Mosasauroidea Camp, 1923

Family Mosasauridae Gervais, 1853

Subfamily Yaguarasaurinae Palci, Caldwell, and Papazzoni, 2013

Referred material: IGM 11194, isolated premaxilla and right maxilla (Figure 7).

Description: A preliminary description of this specimen is available in Zavaleta-Villareal (2015). The pemaxilla is an unpaired compound bone that is drop-like shaped in dorsal view; its anterior edge is rounded, the posterior tapers forming an acute angle where the internarinal bar arises. Although this premaxillary process is almost entirely preserved as an impression; the thin internarinal bar is at least as long as the rest of the premaxilla. The dorsal-lateral surface of this bone is curved and exposes numerous pores of the ophthalmic nerve.

Ventrally, this bone is rather flat and is divided into four regions framed by two crests, one transversal that runs from side to side and other longitudinal that rises behind the anterior edge of this bone and it projects backwards. In each of the two previous regions two teeth are presented forming a line; while the two posterior regions have no teeth (Figure 7).

The right maxilla is an elongated bone tapered anterior and posteriorly, with the ventral edge straight and the dorsal one somewhat sinuous. The premaxilla-maxilla suture border is straight and extends over two maxillary teeth. The posterior edge of this bone is inclined downward from the top, but its bottom develops a thin and long postero -ventral process where there are no more teeth. The labial surface is curved and has a longitudinal axis protruding near the ventral edge of the bone. Although the surface of the maxilla shows nume rous pores of the maxillary nerve; nine of these form a row below the medial longitudinal edge of this bone and are arranged parallel to the ventral edge of this bone (Figure 7).

Eight conical teeth and three empty alveoli are placed on the maxillary alveolar border; these are ordered following the dental formula 1, 2, 3, 4, x, $6, \mathrm{x}, 8,9, \mathrm{x}, 11$. The teeth have ankylosed crowns; they have broad bases protruding from the alveolar maxillary edge. All teeth are entirely smooth and strongly curved backward. In cross section, teeth are rounded at the base, oval in the middle part, and form a weak anterior cutting edge or carina near to the tip (Figure 7).

Remarks: The presence of an unpaired premaxilla (resulting of the fusion of a couple of premaxillae) with four teeth in IGM 11194 supports its identification as a member of the Family Mosasauridae (see Leblanc et al., 2012, among others). According to Palci et al. (2013), the occurrence of tooth roots largely exposed in 


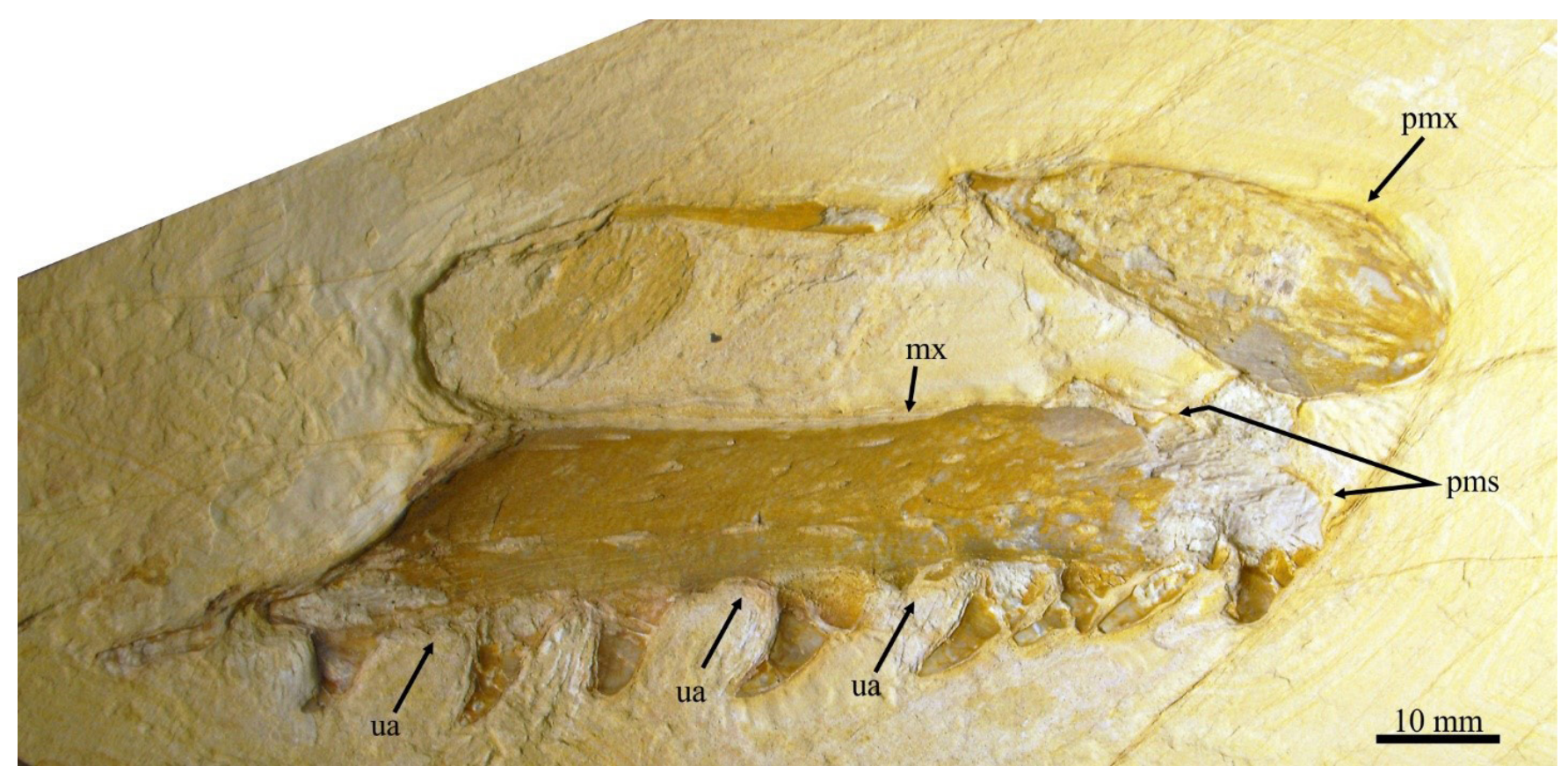

Figure 7 Specimen IGM 11194 , indeterminated Yaguarasaurinae from the San José de Gracia quarry. Abbreviations: mx, maxilla; pmx, premaxilla; pms, premaxilla-maxilla suture; ua, unoccupied or empty alveolus.

medial view of jaw bones represents one of the synapomorphies supporting the monophyly of the subfamily Yaguarasaurinae, which gathers three genera. There include two monospecific genera, Yaguarasaurus columbianus Páramo, 1994, collected in Turonian sediments belonging to Villeta Formation along the Magdalena Valley, Colombia (Páramo, 1994; Páramo-Fonseca, 2000); Russellosaurus coheni Polcyn and Bell, 2005, from the middle Turonian deposits of the Arcadia Park Shale, approximately $15 \mathrm{~cm}$ above Kamp Ranch Limestone, at Cedar Hill, Dallas County, Texas, USA; as well as to species of the genus Romeosaurus Palci, Caldwell, and Papazzoni, 2013, collected in Late Cretaceous localities of Verona, northen Italy, which recently were named as $R$. fumanensis (from the middle Turonian to early Santonian deposits near of the S. Anna di Alfaedo and Fumane villages) and $R$. sorbinii (from the middle Turonian deposits near of the $\mathrm{S}$. Anna di Alfaedo Villages. These characteristics are present in IGM 11194 supporting its recognition as part of this subfamily (Figure 7).
Among other characteristics, the nominal members of Yaguarasaurinae differ from each other by the size of the premaxillary-maxillary suture, as well as the number and shape of maxillary teeth. The suture maxillary-premaxillary is over three maxillary teeth in Romerosaurus while it is over only two maxillary teeth on Maguarasaurus and Russellosaurus (Palci et al., 2013, p. 600). The number of premaxillary teeth is 14-15 in Yaguarasaurus (PáramoFonseca, 2000, p.127), 13-15 in Romeosaurus (Palci et al., 2013, p. 600), and 16 in Rusellosaurus (Polcyn and Bell, 2005, p. 323). The maxillary teeth are moderately curved backward, probably smooth and with no carenae in Yuguarasaurus (PáramoFonseca, 2000, fig. 3); and contrary, teeth are strongly curved, covered with fine medial longitudinal striations, and probably have no carenae in Rusellosaurus (Polcyn and Bell, 2005, fig. 2). Finally, teeth are subcircular in cross section and strongly curved backward in both species of Romeosaurus; however, in $R$. fumanensis there are 15 maxillary teeth, entirely smooth, and bearing weak anterior and posterolateral carinae whereas $R$. sorbinii there 
are 13 maxillary teeth that are ornamented with longitudinal ridges and apparently with no carinae (Palci et al., 2013, p. 601, figs. 2, 4, and 7).

IGM 11194 shows a peculiar combination of features that avoid determining its belonging to any previously known yaguarasaurine genus. In this Mexican fossil the maxillary-premaxillary suture is short as in Maguarasaurus and Russellosaurus (extended over two maxillary teeth). The number of maxillary teeth (1 1) in IGM 11194 is lower than in the nominal yaguarasaurins (13-16). Contrary to $R$. sorbinii, teeth of IGM 11194 are superficially smooth. Peculiarly, in cross section the teeth of IGM 11194 are rounded in the base, ovoid in the middle and clearly compressed laterally in the tip in which there is a small anterior carina. Although the accurate taxonomic identification of IGM 11194 is desirable; this represents a major effort that goes beyond this work. The discovery of IGM 11194 represents the first record of the subfamily Yaguarasaurinae in Mexico.

\subsection{OTHER ELEMENTS IN THE FOSSIL ASSEMBLAGE FROM SAN JOSÉ DE GRAGIA}

For now, about a hundred fossil specimens from San José de Gracia have been catalogued into the Colección Nacional de Paleontología (IGM), UNAM, and a similar amount is within the paleontological collection of the Benemérita Universidada Autónoma de Puebla (BUAP). These fossils show different degrees of conservation, from isolated and fractured elements to complete specimens. Until now, they represent a fossil assemblage that include complete ammonites, belemnites, inoceramids and other indeterminate ostreids, scarce impressions of plants, and vertebrates.

Centimetric coprolites are also preserved in San José de Gracia quarry; these are preserved as phosphatized masses deposited on the bedding planes. In some small fishes, the gastrointestinal contents also preserve similar phosphatic mass. Bony cavities are filled with calcium carbonate crystals. Practically all the fossils from this site are distorted, compressed in a dorsoventral plane, but only some of them show a horizontal elongation that distorts their shape in this plane.

Among the fossils from San José de Gracia, the heteromorph ammonites are remarkable because some of them represent the families Hamitidae and Anisoceratidae, which ranges from Albian to Turonian (Wright et al., 1996) and Albian to Coniacian (Kennedy and Gale, 2015), respectively. Some inoceramids specimens deposited in the BUAP were identified by Gloria Alencáster (JAO, pers. observ.) as potential representatives of the species Inoceramus (Mityloides) labiatus Schlotheim (1813) that has been widely recognized as a fossil species index of the Turonian (Riccardi, 1981; Damian and Lazăr, 2005).

If the temporal distributions of Hamitidae and Anisoceratidae ammonites, the pelecypod Inoceramus labiatus, and the vertebrates described above are considered, it is possible to attribute a Turonian age to the fossiliferous strata exploited in the San José de Gracia quarry (Figure 8). For the moment, the formal studies of all the fossil invertebrates and the possible microfossils of San José de Gracia are pending; once these are

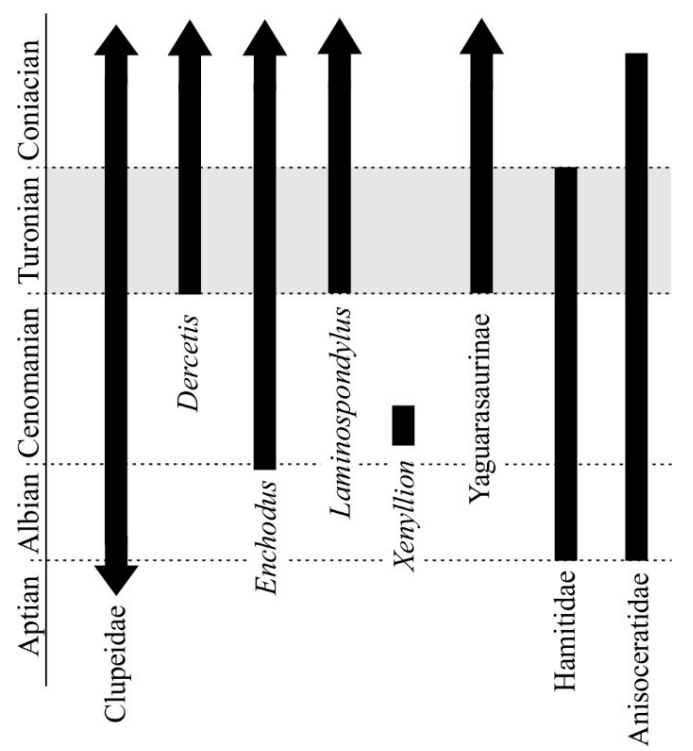

Figure 8 Specimen IGM 11194 , indeterminated Yaguarasaurinae from the San José de Gracia quarry. Abbreviations: $m x$, maxilla; pmx, premaxilla; pms, premaxilla-maxilla suture; ua, unoccupied or empty alveolus. 
developed, it will be possible to reach a more accurate age for this deposit.

\section{Discussion}

Maps already published by Servicio Geológico Mexicano (2006) show that the Oligocene-Miocene continental deposits of the Coatzingo Formation are exposed around the town of San José de Gracia (Figure 1). The base of this continental formation is composed of limestones with some intercalated flint horizons that are covered with a sequence of volcanic ash and sand layers deposited in a lacustrine environment of low energy within the Zacapala Basin (Beraldi-Campesi, 2003). The lithology of the San José de Gracia quarry does not match with that of the Coatzingo Formation; hence, there is no possibility that the rocks of this new locality belong to that formation.

Besides, the local geological framework of San José de Gracia quarry is somewhat complex. In the south, Cambrian-Devonian shales and phyllites belonging to the metamorphic complex of the Acatlán Complex are the oldest rocks in the region (Ortega-Gutiérrez, 1978). Above these Paleozoic strata, there are terrigenous red layers and calcareous lenses from the Upper JurassicEarly Cretaceous (Neocomian-Aptian). Near the town of Tepexi de Rodríguez, a few kilometers south of San José de Gracia, Pantoja Alor (1992) described the Tlayúa Formation as an incomplete sequence, which is recognized as a sequence of at least 300 meters thick composed of marine strata of Aptian-Cenomanian lower age. The low topographic parts near San José de Gracia and Tepexi de Rodríguez show continental Tertiary clastic sediments belonging to different units; among these, the Paleocene-Eocene conglomerates of the Balsas Group (Fries, 1960) lie on the eroded surface of the Tlayúa Formation; above, a Eocene-Oligocene sequence of fluvial, lacustrine and alluvial deposits of the Pie de Vaca Formations as well as a Pleistocene sequence of lacustrine travertines belonging to the Agua de
Luna Formation are present (Pantoja-Alor, 1992; Beraldi-Campesi, 2003; Applegate et al., 2006; among others).

The hills south to San José de Gracia are formed by the Cenomanian massive gray marine limestones of the Morelos Formation, which was originally described by Fries (1960) as a shallow platform marine deposit. Otherwise, the hills and highlands to the East and Northeast of José de Gracia consists of the Aptian marine limestones belonging to Miahuatepec Formation, whose fossil-lacking strata where deposited in shallow conditions (Buitrón and Barceló-Duarte, 1980) (Figure 1).

Regarding its geological context, it is possible to conclude that the marine strata exploited in the San José de Gracia quarry do not belong to any of the Tertiary continental geological units previously documented in this region (Coatzingo, Pie de Vaca, and Agua de Luna). The fossiliferous marly strata of San José de Gracia quarry cannot be identified as part of any of the Early-middle Cretaceous marine limestone formations (Tlayúa, Miahuatepec, and Morelos) previously mapped near San José de Gracia (Figure 1). Therefore, the San José de Gracia fossiliferous strata represent a unit for the first time observed in this region of Puebla.

The sedimentary rocks of Turonian age closest exposed to the SanJosé de Gracia quarry are located $20 \mathrm{~km}$ northwest from this site, along the Atoyac River, and belong to the Mexcala Formation, previously describe by Fries (1960). This formation is a sequence of Cenomanian-Maastrichtian marine sediments deposited within a marginal depocenter, the Morelos-Guerrero Basin, occurred under moderate currents, low turbidity, and pelagic and hemipelagic environments, which today is exposed along Guerrero, Morelos, Puebla, and Oaxaca (Alencáster, 1980; López-Ramos, 1983; Hernández-Romano, 1999; Aguilera-Franco, 2000; among others). It is tempting, based on this observation, to suggest that the San José de Gracía quarry is an outcrop of the Mexcala Formation; however, comparison of the fossil assemblage 
from San José de Gracia quarry with those from Turonian sites (the Arroyo Las Bocas quarry and Taxo El Viejo) of the Mexcala Formation in Guerrero already reported by Alvarado-Ortega et al. (2006b) shows scarce common elements (the occurrence of the genus Enchodus and the family Dercetidae). Today, the recovery of more geological data in the San José de Gracia quarry is problematic, given the small extension and depth of the sequence that is being exploited; hence, the final recognition of the belonging of these rocks to a formal geological unit remains as a pending task.

\section{Conclusions}

The marls of San José de Gracia Quarry, Puebla, Mexico, constitute an outcrop of marine fossiliferous Turonian rocks observed for the first time in this region of Puebla. Although it is possible to suggest these rocks as part of the Mexcala Formation; additional geological data are required to confirm this idea. The fossil vertebrate assemblage recovered from this new site represents an unexpected diversity. This includes taxa previously known in Mexico (such as Enchodus), taxa for the first time recorded in Mexico (such as Dercetis, Xenyllion and Yaguarasaurinae), as well as a specimen that represents the oldest record of the Family Clupeidae in the country (Figure 8).

\section{Acknowledgements}

The authors thank Messrs. Félix and Sebastian Aranguthy for sharing their knowledge of the fossils from the San José de Gracia quarry. We are very grateful to the workers of this quarry for their support and friendship during the fieldworks since 2008. Thoughtful observations and suggestions of Agustin Martinelli and Sergio Bogan allowed improvement to this contribution. Financial support of this project was provided by the UNAM through the grants DGAPA-PAPIIT IN225008, IN106011, and IN207314.

\section{References}

Agassiz, J.L.R., 1833, Recherches sur les poisons fossils, volume 1 (preface dated in 1833): Neuchâtel, Universitat Neuchâtel, 188 p.

Agassiz, J.L.R., 1843, Recherches sur les poisons fossils, volume 2 (preface dated in 1843): Neuchâtel, Universitat Neuchâtel, 356 p.

Agassiz, J.L.R., 1839, Recherches sur les poisons fossils, volume 4: Neuchâtel, Universitat Neuchâtel, 296 p.

Aguilera-Franco, N., 2000, High resolution stratigraphy and palaeoecology of the Cenomanian-Turonian succession, Southern México: London, T.H. Huxley School, University of London, PhD Thesis, 244 p.

Alencáster, G., 1980, Moluscos del Maastrichtiano de Texmalac, Guerrero, in V. Convención Geológica Nacional, Libro-Guía de la Excursión Geológica a la Parte Central de la Cuenca del Alto Río Balsas, estados de Guerrero y Puebla: México, Sociedad Geológica Mexicana Comisión Federal de Electricidad, Universidad Nacional Autónoma de México, Instituto de Geología, 39-42.

Alvarado-Ortega, J., González-Rodríguez, K.A., Blanco-Piñón, A., Espinosa-Arrubarrena, L., Ovalles-Damián, E., 2006a, Mesozoic osteichthyans of Mexico, in Vega, F.J., Nyborg, T., Perrilliat, M. del C., MontellanoBallesteros, M., Cevallos-Ferriz S.R.S., Quiroz-Barroso, S.A. (eds.), Studies on Mexican Paleontology: Netherlands, Springer, 169-207.

Alvarado-Ortega, J., Garibay-Romero, L.M., Blanco-Piñón, A., González-Barba, G., Vega-Vera, F.J., Centeno-García, E., 2006b, Los peces fósiles de la Formación 
Mexcala (Cretácico Superior) en el Estado de Guerrero, México: Revista Brasileira de Paleontología, 9(3), 261-272. https://doi. org/10.4072/rbp.2006.3.01

Alvarado-Ortega, J., Ovalles-Damián, E., BlancoPiñón, A., 2009, The fossil fishes from the Sierra Madre Formation, Ocozocoautla, Chiapas, Southern Mexico: Palaeontologia Electronica, 12, 1-22.

Applegate, S.P., Espinosa-Arrubarrena, L., Alvarado-Ortega, J., Benammi, M., 2006. Revision of recent investigations in the Tlayúa Quarry, in Vega, F.J., Nyborg, T., Perrilliat, M. del C., Montellano-Ballesteros, M., Cevallos-Ferriz S.R.S., Quiroz-Barroso, S.A. (eds.), Studies on Mexican Paleontology: Netherlands, Springer, 275-304.

Arambourg, C., 1954, Les poissons crétacés du Jebel Tselfat (Maroc): Moroc, Éd. du Service géologique du Maroc, 188 p.

Beraldi Campesi, H.B., 2003, Estratigrafía, sedimentología y paleontología de una porción de la Formación Pie de Vaca, Tepexi de Rodríguez, Puebla: México, Universidad Nacional Autónoma de México, Masters degree Thesis, $65 \mathrm{p}$.

Blanco-Piñón, A., 1998, Vallecillo, Nuevo León: yacimiento fosilífero del Noreste de México. Programa de posgrado: Nuevo León, Universidad Autónoma de Nuevo León, Masters degree Thesis, $148 \mathrm{p}$.

Bogan, S., Agnolin F.L., 2010, Primera ictiofauna marina del Cretácico superior (Formación Jaguel, Maastrichtiano) de la provincia de Río Negro, Argentina: Papéis Avulsos de Zoologia, 50, 175-188.

Borden, W.C., Grande, T., Smith, W.L., 2013, Comparative osteology and myology of the caudal fin in the Paracanthopterygii (Teleostei: Acanthomorpha), in Arratia, G., Schultze, H.-P., Wilson, M.V.H. (eds.), Mesozoic Fishes -Global Diversity and Evolution-: München, Germany, Verlag Dr. Pfeil, 419-455.
Buitrón, B.E., Barceló-Duarte,J., 1980, Nerineidos (Mollusca-Gastropoda) del Cretácico Inferior de la región de San Juan Raya, Puebla: Revista Mexicana de Ciencias Geológicas, 4, 46-55.

Camp, C.L., 1923, Classification of the lizards: Bulletin of American Museum of Natural History, 48, 289-481.

Carbot-Chanona, G., Than-Marchese, B.A., 2013. Presencia de Enchodus (Osteichthyes: Aulopiformes: Enchodontidae) en el Maastrichtiano (Cretácico tardío) de Chiapas, México: Paleontología Mexicana, 63, 8-16.

Cavin, L., Alexopoulos, A., Piuz, A., 2012, Late Cretaceous (Maastrichtian) ray-finned fishes from the island of Gavdos, southern Greece, with comments on the evolutionary history of the aulopiform teleost Enchodus: Bulletin de la Société Géologique de France, 183, 561-572.

Chalifa, Y., 1996, New species of Enchodus (Aulopiformes: Enchodontidae) from the Northern Negev, Israel, with comments on evolutionary trends in the Enchodontoidei, in Arratia, G., Viohl, G. (eds.), Mesozoic Fishes - Systematics and Paleoecology-: München, Germany, Verlag Dr. Friedrich Pfeil, 349-367.

Cope, E.D., 1874, Review of the vertebrata of the Cretaceous period found west of the Mississippi River: U.S. Geological and Geographical Survey of the Territories Bulletin, 1, 2-48.

Cope, E.D., 1875, The Vertebrata of the Cretaceous formations of the West: Report of U.S. Geological Survey of the Territories (Hayden), 2, 1-303.

Cuvier, G.L.G.F.G., 1817, Regne animal, 1st edition, vol. 2: Paris, 532 p.

Damian, R., Lazăr, L., 2005, The stratigraphic position of the Late Cretaceous inoceramids from the Olăneşti-Cheia Basin (Southern Carpathians): Acta Palaeontologica Romaniae, 5, 96-106. 
Díaz-Cruz, J.A., Alvarado-Ortega, J., CarbotChanona, G., 2016, The Cenomanian short snout enchodontid fishes (Aulopifomes, Enchodontidae) from Sierra Madre Formation, Chiapas, southeastern Mexico: Cretaceous Research, 61, 136-150. https:// doi.org/10.1016/j.cretres.2015.12.026

Fielitz, Ch., 2004, The phylogenetic relationships of the $\dagger$ Enchodontidae (Teleostei: Aulopiformes), in Arratia, G., Wilson, M. V. H., Cloutier, R. (eds.), Recent Advances in the Origin and Early Radiation of Vertebrates: München, Verlag Dr. Friedrich Pfeil, 619-634.

Fielitz, C., González-Rodríguez. K.A., 2010, A new species of Enchodus (Aulopiformes: Enchodontidae) from the Cretaceous (Albian to Cenomanian) of Zimapán, Hidalgo, México: Journal of Vertebrate Paleontology, 30(5), 1343-1351. https://doi.org/10.1080/ 02724634.2010 .501438

Figueiredo F. J., 2009, A new marine clupeoid fish from the Lower Cretaceous of the SergipeAlagoas Basin, northeastern Brazil: Zootaxa, 2164(1), 21-32. https://doi.org/10.11646/ zootaxa.2164.1.2

Fries, C.Jr., 1960, Geología del Estado de Morelos y partes adyacentes de México y Guerrero, Región central Meridional de México: Boletín del Instituto de Geología, 60, 1-236.

Gervais, P., 1853, Observations relatives aux reptiles fossiles de France (première partie): Comptes Rendus de l'Académie des Sciences de Paris, 36, 374-77.

Giersch, S., 2014, Die Knochenfische der Oberkreidezeit in Nordostmexiko: Beschreibung, Systematik, Vergesells chaftung, Paläobiogeographie und Paläoökologie: Heidelberg, RuprechtKarls-Universität Heidelberg, Doctoral dissertation, $275 \mathrm{p}$.

Giersch, S., Frey, E., Stinnesbeck, W., Gonzalez Gonzalez A.H., 2008, Fossil fish assemblages of northeastern Mexico: New evidence of Mid Cretaceous actinopterygian radiation, in $6^{\text {th }}$ Meeting of the European Association of Vertebrate Palaeontologists, Spiŝská Nová Ves, Slovak Republic, Krempská, Z. (ed.), Volume of abstracts, 43-45.

González-Barba, G., Espinosa-Chávez, B., 2005, Cenomanian-Turonian fish fauna from the Boquillas Formation at Jaboncillos, north-west Coahuila, Mexico, in Fourth Internacional Meeting on Mesozoic Fishes Systematics, Homology, and Nomenclature-: Miraflores de la Sierra, Madrid, España, Poyato-Ariza, F. J. (ed.), Extended Abstracts, 105-107.

Goody, P.C., 1969, The relationships of certain Upper Cretaceous Teleosts with special reference to the Myctophoids: Bulletin of the British Museum (Natural History), 7, 1-255.

Goody, P.C., 1976, Enchodus (Teleostei: Enchodontidae) from the Upper Cretaceous Pierre Shale of Wyoming and South Dakota with an evaluation of the North American enchodontid species: Palaeontographica Abteilung A Band A152, Lieferung, 4-6, 91-112.

Grande, L., 1985, Recent and fossil Clupeomorph fishes with materials for revision of the subgroups of Clupeoids: Bulletin of the American Museum of Natural History, 181, 231-372.

Greenwood, P.H., Rosen, D.E., Weitzman, S. H., Myers, G.S., 1966, Phyletic studies of teleostean fishes, with a provisional classification of living forms: Bulletin of the American Museum of Natural History, 131, 4, 139-456.

Hernández-Romano, U., 1999, Facies, stratigraphy, and diagenesis of the Cenomanian-Turonian of the Guerrero-Morelos Platform, southern México: United Kingdom, Postgraduate Research Institute for Sedimentology, University of Reading, PhD Thesis, 322 p. 
Holloway, W.L., Claeson, K.M., Sallam, H. M., El-Sayed, S., Kora, M., Sertich, J.J., O'Connor, P.M., 2017, A new species of the neopterygian fish Enchodus from the Duwi Formation, Campanian, Late Cretaceous, Western Desert, central Egypt: Acta Palaeontologica Polonica, 62, 603-611. https://doi.org/10.4202/app.00331.2016

Kaddumi, H.F., 2006, A new genus and species of gigantic marine turtles (Chelonioidea: Cheloniidae) from the Maastrichtian of the Harrana Fauna-Jordan: PalArch, 3, 1-13.

Kennedy, W.J., Gale, A.S., 2015, Late Turonian ammonites from Haute-Normandie, France: Acta Geologica Polonica, 65(4), 507-524. https://doi.org/10.1515/agp-2015-0022

Lavoué, S., Miya, M., Musikasinthorn, P., Chen, W.J., Nishida, M., 2013, Mitogenomic evidence for an Indo-west Pacific origin of the Clupeoidei (Teleostei: Clupeiformes): PLoS One, 8(2), e56485. https://doi. org/10.1371/journal.pone.0056485

Leblanc, A.R., Caldwell, M.W., Bardet, N., 2012, A new mosasaurine from the Maastrichtian (Upper Cretaceous) phosphates of Morocco and its implications for mosasaurine systematics. Journal of Vertebrate Paleontology, 32(1), 82-104. https://doi.org /10.1080/02724634.2012.624145

Leidy, J., 1855, Indications of twelve species of fossil fishes: Proceedings of the Academy of Natural Sciences of Philadelphia, 7, 395-397.

Leidy, J., 1856, Description of two ichthyodoru lites: Proceedings of the Academy of Natural Science of Philadelphia, 8, 11-12.

Leidy, J., 1857, Notices of some remains of extinct fishes: Proceedings of the Academy of Natural Sciences of Philadelphia, 9, 167-168.

López-Ramos, E.,1983, Geología de México, vol. 3, Tomo 2: D.F., México, Edición Escolar (3 ${ }^{\text {a }}$ Edición), 454 p.
Malabarba, M.C., Di Dario, F., 2017, A new predatory herring-like fish (Teleostei: Clupeiformes) from the early Cretaceous of Brazil, and implications for relationships in the Clupeoidei: Zoological Journal of the Linnean Society, 180, 175-194.

Maldonado-Koerdell, M., 1956, Peces fósiles de México III, Nota preliminar sobre peces del Turoniano superior de Xilitla, San Luis Potosí, México: Ciencia (México), 16, 31-36. Mantell, G.A., 1822, The Fossils of the South Downs: Or, Illustrations of the Geology of Sussex: London, Lupton Relfe, 320 p. + XLII pl.

Murray, A.M., Wilson, M.V., 1999, Contributions of fossils to the phylogenetic relationships of the percopsiform fishes (Teleostei: Paracanthopterygii): order restored, in Arratia, G., Schultze, H.-P. (eds.), Mesozoic Fishes 2 - Systematics and the Fossil Record: München, Verlag Dr. Friedrich Pfeil, 397-411.

Nelson, J.S., Grande, T.C., Wilson, M.V.H., 2016, Fishes of the World: New Jersey, John Wiley \& Sons, 752 p. https://doi. org/10.1002/9781119174844

Newbrey, M.G., Murray, A.M., Wilson, M.V., Brinkman, D.B., Neuman, A.G., 2013, A new species of the paracanthopterygian Xenyllion (Sphenocephaliformes) from the Mowry Formation (Cenomanian) of Utah, USA, in Arratia, G., Schultze, H.-P., Wilson, M.V.H. (eds.), Mesozoic Fishes 5 - Global Diversity and Evolution: München, Verlag Dr. Friedrich Pfeil, 363-384.

Oppel, M., 1811, Die ordnungen, familien und gattungen der reptilien als prodrom einer naturgeschichte derselben: München, Joseph Lindauer, 86 p.

Ortega-Gutiérrez, F., 1978, Estratigrafía del Complejo Acatlán en la Mixteca baja, estados de Puebla y Oaxaca: Boletín del Instituto de Geología, 2, 112-134. 
Palci, A., Caldwell, M.W., Papazzoni, C.A., 2013, A new genus and subfamily of mosasaurs from the Upper Cretaceous of northern Italy: Journal of Vertebrate Paleontology, 33(3), 599-612. https://doi.org/10.1080/02 724634.2013 .731024

Pantoja-Alor, J., 1992, Geología y paleoambientes de la Cantera Tlayúa, Tepexi de Rodríguez, estado de Puebla: Universidad Nacional Autónoma de México, Instituto de Geología, Revista, 9(2), 156-169.

Páramo, M.E., 1994, Posición sistemática de un reptil marino con base en los restos fósiles encontrados en capas del Cretácico superior en Yaguará (Huila): Revista de la Academia Colombiana de Ciencias Exactas, Físicas y Naturales, 19, 63-80.

Páramo-Fonseca, M.E., 2000, Yaguarasaurus columbianus (Reptilia, Mosasauridae), a primitive mosasaur from the Turonian (Upper Cretaceous) of Colombia: Historical Biology, 14(1-2), 121-131. https://doi. org/10.1080/10292380009380560

Parris, D.C., Grandstaff, B.S., Gallagher, W. B., 2007, Fossil fish from the Pierre Shale Group (Late Cretaceous): clarifying the biostratigraphic record: Geological Society of America Special Papers, 427, 99-109. https://doi.org/10.1130/2007.2427(07)

Patterson, C., 1964, A review of Mesozoic Acanthopterygian fishes, with special reference to those of the English Chalk: Philosophical Transactions of the Royal Society, London, 247(739), 213-482. https:// doi.org/10.1098/rstb.1964.0003

Patterson, G., Rosen, D.E., 1989, The Paracanthopterygii revisited: order and disorder, in Cohen, D.M. (ed.), Papers on the systematics of gadiform fishes, 32: Los Angeles, California, Natural History Museum of Los Angeles County, 5-36.
Pictet, F.-J., 1850, Description de quelques poissons fossiles du Mont Liban: Genève, Jules-Guillaume Fick., 56 p. +9 pl.

Polcyn, M.J., Bell, G.L., 2005, Russellosaurus coheni n. gen., n. sp., a 92 million-yearold mosasaur from Texas (USA), and the definition of the parafamily Russellosaurina: Netherlands Journal of Geosciences, 84(3), 321-333. https://doi.org/10.1017/ s0016774600021107

Pulido-González, E.P., 2011, Descripción e identificación de los fósiles índice de la Cantera San José de Gracia, Puebla: Puebla, Escuela de Biología, Benemérita Universidad Autónoma de Puebla, Bachelors Thesis, 51 p.

Riccardi, A.C., 1981, An Upper Cretaceous ammonite and inoceramids from the Honna Formation, Queen Charlotte Islands, British Columbia: Geological Survey of Canada Gurrent Research, Part C 81(1C), 1-8.

Romero-García, A.E., 2013, Descripción y comparación del género Enchodus (Teleostei, Aulopiformes) de San José de Gracia, Puebla, México: D.F., México, Facultad de Ciencias, Universidad Nacional Autónoma de México, Bachelors thesis, $66 \mathrm{p}$.

Rosen, D.E., 1973, Interrelationships of higher euteleostean fishes, in Greenwood, P.H., Miles, R.S., Patterson, G. (eds.), Interrelationships of fishes: London, Academic Press, 397-513.

Rosen, D.E., Patterson C., 1969, The structure and relationships of the paracanthopterygian fishes: Bulletin of the American Museum of Natural History, 141, 357-474.

Schlotheim, E.F. von, 1813. Beiträge zur Naturgeschichte der Versteinerungen in geognostischer Hinsicht: Leonhard's Taschenbuch für die gesammte Mineralogie mit Hinsicht auf die neuesten Entdeckungen, 7, 3-134. 
Servicio Geológico Mexicano (SGM), 2006, Carta Geológico-Minera Molcaxac E14-B64, escala 1:50000: Pachuca, Hidalgo, Servicio Geológico Mexicano, 1 mapa com texto.

Silva, H., Gallo, V., 2011, Taxonomic review and phylogenetic analysis of Enchodontoidei (Teleostei: Aulopiformes): Anais da Academia Brasileira de Ciências, 83(2), 483-511. https://doi.org/10.1590/ s0001-37652011000200010

Taverne, L., 1987, Ostéologie de Cyranichthys ornatissimus nov. gen. du Cénomanien du Zaire et de Rhynchodercetis yovanovitchi du Cénomanien de l'Afrique du Nord. Les relations intergeneriques et la position systématique de la famille neocrétacique marine des Dercetidae (Pisces, Teleostei): Annales du Musée Royal de l'Afrique Centrale, Tervuren, Rapport Annuel, 19851986, 93-112.

Taverne, L., 2005a, Les poissons crétacés de Nardo. 22. Nardodercetis vandewallei gen. et sp. nov. (Teleostei, Aulopiformes, Dercetidae): Bollettino del Museo Civico di Storia Naturale di Verona, Geologia Paleontologia Preistoria, 29, 81-93.

Taverne, L., 2005b, Les poisons crétacés de Nardo. 21. Ophidercetis italiensis gen. et sp. nov. (Teleostei, Aulopiformes, Dercetidae). Une solution osteologique au probleme des genres Dercetis et Benthesikyme (Leptotrachelus): Bollettino del Museo Civico di Storia Naturale di Verona, Geologia Paleontologia Preistoria, 29, 55-79.

Taverne, L., 2006, Les poissons crétacés de Nardò. $24^{\circ}$. Caudadercetis bannikovi gen. et sp. nov. (Teleostei, Aulopiformes, Dercetidae). Considérations sur la phylogénie des Dercetidae: Bollettino del Museo Civico di Storia Naturale di Verona, Geologia Paleontologia Preistoria, 30, 29-50.

Vernygora, O., Murray, A.M., Luque, J., Ruge, M. L.P., Fonseca, M.E.P., 2017, Anew Cretaceous dercetid fish (Neoteleostei: Aulopiformes) from the Turonian of Colombia: Journal of Systematic Palaeontology, 1-15.

Wiley, E.O., Johnson, G.D., 2010, A teleost classification based on monophyletic groups, in Nelson, J.S., Schultze, H.-P., Wilson, M.V.H. (eds.), Origin and Phylogenetic Interrelationships of Teleosts: München, Verlag Dr. Friedrich Pfeil, 123-182.

Wilson, M.V.H., Murray, A.M., 1996, Early Cenomanian acanthomorph teleost in the Cretaceous Fish Scale Zone, Albian/ Cenomanian boundary, Alberta, Canada, in Arratia, G., Viohl, G., (eds.), Mesozoic fishessystematics and paleoecology: München, Verlag Dr. Friedrich Pfeil, 369-382.

Woodward, A.S., 1901, Catalogue of fossil fishes in the British Museum (Natural History). Part 4: London, British Museum (Natural History), $636 \mathrm{p}$.

Wright, C.W., Callomon, J.H., Howarth, M. K., 1996, Cretaceous Ammonoidea, in Kaesler, R.L. (ed.), Treatise on invertebrate paleontology. Part L. Mollusca 4: Lawrence, Geological Society of America and University of Kansas Press, 362 p.

Zavaleta-Villareal, V., 2015, Revisión de los mosasaurios (Squamata, Mosasauroidea) Mexicanos: D.F., México, Posgrado en Ciencias Biológicas, Universidad Nacional Autónoma de México, Masters degree Thesis, 103 p.. 